\title{
The seasonal radon survey and assessment of annual effective dose in some dwellings near the registered uranium mining lot areas in Korea
}

\author{
G.H. Kim ${ }^{1}$, B.U. Chang ${ }^{1,2}$, Y.J. Kim ${ }^{1,2}$, M.H. Song ${ }^{2}$ and K.W. Cho ${ }^{1,2}$ \\ ${ }^{1}$ University of Science \& Technology, Gwahak-ro 113, Yuseong-gu, 305-333 Daejeon, \\ Republic of Korea, \\ ${ }^{2}$ Korea Institute of Nuclear Safety, Gwahak-ro 34, Yuseong-gu, 305-338 Daejeon, \\ Republic of Korea
}

\begin{abstract}
Seasonal indoor radon concentration was surveyed, and the annual effective dose was estimated for the residents in some dwellings near the registered uranium mining lot areas, considered as one of the potential radon-prone area. The range of indoor radon concentration in each dwelling was from 17.7 to $1,610 \mathrm{~Bq} \cdot \mathrm{m}^{-3}$. The range of annual effective dose due to inhaled radon of the resident in each dwelling was from 0.93 to $20.5 \mathrm{mSv}$.
\end{abstract}

\section{INTRODUCTION}

Radon is one of the most dominant natural radionuclide in the most environment, and the radon is generated from the decay product of Uranium $\left({ }^{238} \mathrm{U},{ }^{235} \mathrm{U}\right)$ and Thorium $\left({ }^{232} \mathrm{Th}\right)$. Radon is colorless and odorless radioactive noble gas, so it is easily released through the ground surface. And then, radon is flowed into the indoor through the cracks in the bottom of the building [1].

In the UNSCEAR 2000 reports, it is estimated that the annual effective dose by radon and its progeny is $1.15 \mathrm{mSv}$, which corresponds to about $50 \%$ of total public exposure dose rate, $2.4 \mathrm{mSv}$, by natural soureces radiation. It is also estimated that most exposure by radon and radon progeny is occurred from the inhalation of household air [2]. So, the management of exposure by radon is one of the most effective ways to reduce public exposure dose. In ICRP, it is recommended that defining radon-prone area needs to effective manage of indoor radon concentration and can be focused on radon where it is most critical and action to be concentrated where it is most likely to be effective. It is also referred that the most reliable way to define radon-prone area is to use the measuring the radon concentrations in a representative sample of existing dwellings [3].

Since 1989, national radon in Korea was surveyed continuously, and the results of these surveys were indicated that indoor radon concentration in some dwellings in some regions were higher than reference level $\left(300 \mathrm{~Bq} \cdot \mathrm{m}^{-3}\right)$ of ICRP and the high radon areas were founded in central part of Korea, which were related to radium concentration in surface soil [4-6]. About 5,600 dwellings were surveyed [4], and the survey result was not enough to define radon-prone area because of insufficient survey results for indoor radon. For this reason, the vicinity of registered uranium mining lot areas can be considered as one of the radon-prone area. The radium concentration in the surface soil in the registered uranium mining lot areas can be possibly high, and indoor radon concentration in these regions can be possibly high too. Also, residents lived in these areas were exposes to possibly high radiation dose. Therefore, the identification of these areas that are regarded as potential radon-prone area is needed through the indoor radon survey in these areas. 


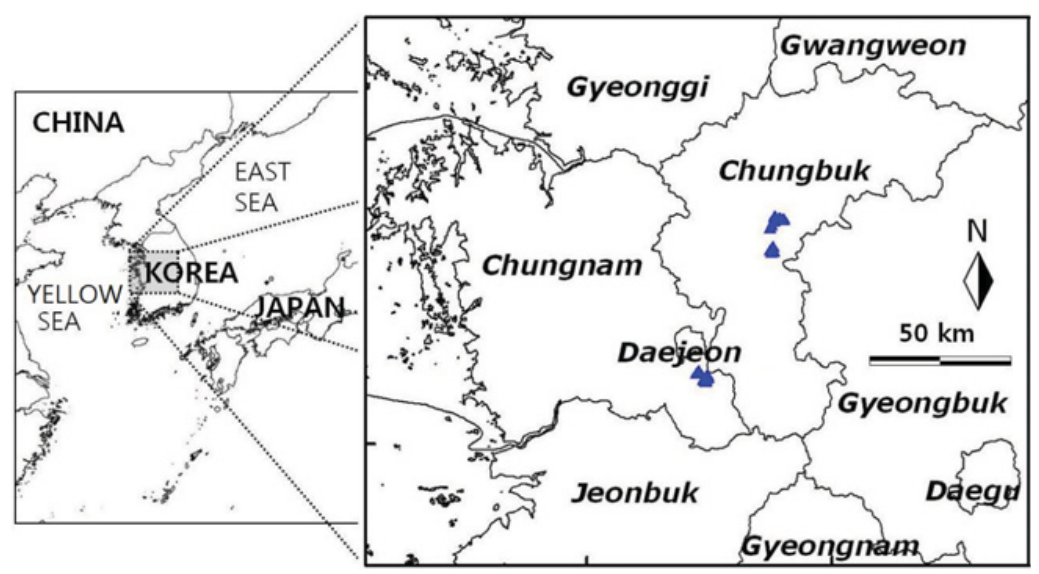

Figure 1. The location map of the selected dwellings. The triangle symbols are the point of the surveyed dwellings.

In this study, a seasonal survey on indoor radon concentration for some dwellings near the several registered uranium mining lot areas was conducted, and based on the lifestyle of residents, the exposure dose to the residents in these dwellings was assessed in detail.

\section{MATERIALS AND METHODS}

Twenty dwellings were selected to carry out seasonal survey for four three-month periods (March 2010February 2011), based on the preliminary survey in randomly selected seventy five dwellings of some currently registered uranium mining lot areas in Korea [7] (Sangso, Cheongcheon, Chubu), during two months in winter season (December 2009-February 2010). Location map of twenty selected dwellings were shown in Figure 1.

For measurement of seasonal radon concentration, the detectors were placed and retrieved in each quarter. The detectors were placed in the bedroom and/or living room in each dwelling. The solid state nuclear track detectors (SSNTD; Raduet ${ }^{\circ}$, Radosys Co., LTD, Hungary) were used for indoor radon measurement. The detector consists of two different diffusion chambers, so it can measure both radon $\left({ }^{222} \mathrm{Rn}\right)$ and thoron $\left({ }^{220} \mathrm{Rn}\right)$ concentration separately. After the measurement of radon during each 3 months, the CR-39 chips in the detectors were taken out and chemically etched with $6.25 \mathrm{M} \mathrm{NaOH}$ solution at $90^{\circ}$ for 4.5 hours in the laboratory, and alpha tracks on the CR-39 chip were counted with the alpha track reading system (RSV-6, Radosys Co., LTD, Hungary) [8].

For systematic assessment of the annual effective dose, residential pattern of each resident were investigated using individual questionnaires, which included the type of occupation, seasonal residential time of resident, age of each resident and ventilation habit. On the basis of these information, the seasonal representative residential time was calculated and the seasonal effective dose of the residents was calculated by the dose calculation method given in UNSCEAR 2000 report (Equation (1)) [2] using the seasonal radon concentrations and the representative residential time.

$$
\begin{gathered}
E_{s}=C_{s} \times T_{s} \times F \times D \\
E_{y}=E_{\text {Spring }}+E_{\text {Summer }}+E_{\text {Fall }}+E_{\text {Winter }}
\end{gathered}
$$

Where, $C_{s}$ is the seasonal radon concentration in each dwelling and $T_{S}$ is the seasonal representative residential time from the individual questionnaires. $F$ is an equilibrium factor between indoor radon and its decay product, which was 0.4 hours given in UNSCEAR 2000 Report [2]. $D$ is the dose conversion coefficient which is applied $12 \mathrm{nSv} \cdot\left(\mathrm{Bq} \cdot \mathrm{m}^{-3} \cdot \mathrm{h}\right)^{-1}$ provided in the ICRP Statement on Radon 
Table 1. The seasonal variation of radon concentration and the annual average in each dwelling.

\begin{tabular}{|c|c|c|c|c|c|c|}
\hline \multirow[t]{2}{*}{ Township } & \multirow{2}{*}{$\begin{array}{c}\text { Dwelings } \\
\text { code }\end{array}$} & \multicolumn{4}{|c|}{ Seasonal variation of radon Concentration $\left(\mathbf{B q} \cdot \mathbf{m}^{-3}\right)$} & \multirow{2}{*}{$\begin{array}{c}\text { Annual } \\
\text { arithmetic } \\
\text { average } \\
\left(\mathbf{B q} \cdot \mathbf{m}^{-3}\right)\end{array}$} \\
\hline & & $\mathbf{1}^{\text {st }}$ (Spring) & $2^{\text {nd }}$ (Summer) & $\mathbf{3}^{\text {rd }}($ Fall $)$ & $4^{\text {th }}$ (Winter) & \\
\hline \multirow{2}{*}{ Sangso(SS) } & SS-1 & $251 \pm 9$ & $161 \pm 6$ & $353 \pm 7$ & $749 \pm 14$ & 397 \\
\hline & SS-2 & $23.8 \pm 1.7$ & $22.2 \pm 2.1$ & $37.7 \pm 2.1$ & $87.3 \pm 3.9$ & 43 \\
\hline \multirow{11}{*}{$\begin{array}{l}\text { Cheongcheon } \\
\text { (CC) }\end{array}$} & CC-1 & $106 \pm 4$ & $75.9 \pm 4$ & $300 \pm 7$ & $419 \pm 10$ & 225 \\
\hline & $\mathrm{CC}-2$ & $342 \pm 6$ & $38.0 \pm 2.6$ & $365 \pm 6$ & $1,050 \pm 13$ & 449 \\
\hline & CC-3 & $20.6 \pm 2.8$ & $22.7 \pm 3.7$ & $31.5 \pm 3.3$ & $45.6 \pm 5.1$ & 30 \\
\hline & CC-4 & $27.1 \pm 2.2$ & $31.0 \pm 3.0$ & $57.6 \pm 3.1$ & $110 \pm 5.4$ & 57 \\
\hline & CC-5 & $511 \pm 6$ & $65.8 \pm 2.9$ & $600 \pm 7$ & $1,230 \pm 13$ & 597 \\
\hline & CC-6 & $275 \pm 6$ & $212 \pm 6$ & $668 \pm 11$ & $923 \pm 15$ & 520 \\
\hline & CC-7 & $358 \pm 4$ & $108 \pm 4$ & $479 \pm 6$ & $1,000 \pm 11$ & 467 \\
\hline & CC-8 & $270 \pm 4$ & $57.4 \pm 2.4$ & $247 \pm 4$ & $1,610 \pm 13$ & 545 \\
\hline & CC-9 & $65.6 \pm 2.7$ & $38.4 \pm 3.2$ & $113 \pm 4$ & $332 \pm 9$ & 129 \\
\hline & CC-10 & $190 \pm 5$ & $23.2 \pm 2.6$ & $348 \pm 7$ & $685 \pm 13$ & 311 \\
\hline & CC-11 & $34.8 \pm 3.5$ & $40.9 \pm 4.7$ & $29.6 \pm 3.2$ & $57.3 \pm 5.6$ & 41 \\
\hline \multirow{7}{*}{ Chubu(CB) } & CB-1 & $111 \pm 6$ & $34.4 \pm 3.0$ & $190 \pm 5$ & $453 \pm 11$ & 209 \\
\hline & CB-2 & $276 \pm 9$ & $17.7 \pm 2.9$ & $577 \pm 12$ & $1,010 \pm 22$ & 476 \\
\hline & CB-3 & $24.7 \pm 2.9$ & $29.6 \pm 4.0$ & $49.3 \pm 4.0$ & $50.5 \pm 5.4$ & 39 \\
\hline & CB-4 & $199 \pm 8$ & $24.6 \pm 3.7$ & $190 \pm 8$ & $475 \pm 16$ & 222 \\
\hline & CB-5 & $287 \pm 9$ & $36.5 \pm 4.4$ & $196 \pm 8$ & $541 \pm 17$ & 265 \\
\hline & CB-6 & $46.9 \pm 3.9$ & $33.8 \pm 4.3$ & $62.7 \pm 4.5$ & $49.8 \pm 13.0$ & 48 \\
\hline & CB-7 & $377 \pm 11$ & $73.5 \pm 4.3$ & $251 \pm 6$ & $631 \pm 13$ & 327 \\
\hline
\end{tabular}

in November 2009 [9]. From these factors, the seasonal effective $\operatorname{dose}\left(E_{s}\right)$ by the radon inhalation were calculated, and the annual effective dose $\left(E_{y}\right)$ was assessed from seasonal effective dose in each resident by the equation (2).

\section{RESULTS}

The range of the seasonal Indoor radon concentration in each dwelling was 18.3-511, 17.7-212, 29.6-668, 45.6-1,610 Bq. $\mathrm{m}^{-3}$, respectively. Some dwellings were shown significantly high radon concentration. Totally, 9 dwellings were over the radon upper value of reference level at dwellings (300 $\mathrm{Bq} \cdot \mathrm{m}^{-3}$ ) recommended by ICRP statement on Radon in November 2009 [9]. The seasonal variation of radon concentration and the annual average in each dwelling were summarized in Table 1.

Indoor radon concentrations in winter season are higher than any other season (Table 1). In general, Indoor radon concentration is affected by some causes, such as temperature, humidity, pressure, and ventilation habits of each resident. Especially, temperature differences between indoors and outdoors produce a pressure gradient across the building shell which is called the stack effect. This driving force is particularly important during cold seasons when it induces and inward flow of radon rich air from surrounding soil to the inside of dwellings [10].

The surveyed residence in this study is located in farm village, and almost type of dwellings is the detached and altered Korean-style dwellings. Almost dwellings are in contact with the ground, because of the single floor, and these dwellings are old and have many cracks on the floor. For these reasons, the indoor radon concentration of the most survey dwellings in registered uranium mining lot areas were relatively high. Indoor radon concentration of some dwellings was relatively low. The 
Table 2. The representative daily working time and seasonal residential time.

\begin{tabular}{|c|c|c|c|c|}
\hline \multirow{2}{*}{ periods } & \multicolumn{2}{|c|}{ A day working time } & \multirow{2}{*}{$\begin{array}{l}\text { A day residential } \\
\text { time (hours) }\end{array}$} & \multirow{2}{*}{$\begin{array}{c}\text { Seasonal residential } \\
\text { time (hours) }\end{array}$} \\
\hline & Start & End & & \\
\hline Mar.-May (1 ${ }^{\text {st }} ;$ Spring) & 09:00 am & 17:00 pm & 16 & 1,472 \\
\hline Jun.-Aug. ( $2^{\text {nd }} ;$ Summer $)$ & 08:00 am & $19: 00 \mathrm{pm}$ & 13 & 1,196 \\
\hline Sep.-Nov. $\left(3^{\text {rd }} ;\right.$ Fall $)$ & 08:00 am & $18: 00 \mathrm{pm}$ & 14 & 1,274 \\
\hline Dec.-Feb. $\left(4^{\text {th }} ;\right.$ Winter $)$ & \multicolumn{2}{|c|}{ No work } & 24 & 2,160 \\
\hline
\end{tabular}

radon concentration in Korea-style dwellings (CC-3, CC-11, CB-6) was lower than any other type of dwellings. These dwellings are the unaltered Korean-style dwellings, which have 'ondol' system. The ondol is the traditional heating system in Korea, and uses direct heat transfer from wood smoke to the underside of a thick masonry floor. Because the empty space that is under the floor in ondol system is the function as the radon-sump, the inflow of radon into the dwellings is prevented. Also, the door and window consist of the wood and "hanji", which is Korean paper, in these dwellings. So, outflow of indoor radon is better than the western-style dwellings or the remodeling Korea-style dwelling, which is altered the glass windows. Therefore, the indoor radon concentration in the unaltered Korean-style dwellings, which have ondol system, is relatively low.

According to the result of the questionnaire, the most residents have engaged in agriculture and are similar age. Farming is generally associated with the season. For this reason, the seasonal work pattern is different, and residential time is seasonally different too. Also, most of them are elderly and they spent the most of the time in dwellings in off-hours. Especially in winter season, farming is not carried out. So, residential time in winter is longer than any other seasons. Because the most residents have similar seasonal work pattern and seasonal residential time, representative residential time for seasonal was set for applied assessment of annual effective dose. The representative daily working time and seasonal residential time were summarized in Table 2.

On the basis of the seasonal indoor radon concentration and the representative residential time, systematic annual effective dose of the residents in each dwelling was assessed. The seasonal effective dose and the annual effective dose in each dwelling were summarized in Table 3 and Figure 2.

The range of the seasonal effective dose in each dwelling was $0.13-3.61,0.10-1.22,0.18-4.09$, $0.47-16.7 \mathrm{mSv} \cdot \mathrm{y}^{-(1 / 4)}$, respectively. The annual effective dose of the residents in each dwelling was founded out from 0.93 to $20.5 \mathrm{mSv} \cdot \mathrm{y}^{-1}$. These values were slightly higher (approximately 5-10\%) than the calculated conventional annual effective doses by UNSCEAR 2000 using the annual residential time $(7000 \mathrm{~h})$ and the annual average of radon concentration. The annual effective dose of some residents were over the radon upper value of reference level at dwellings $(10 \mathrm{mSv})$ recommended by ICRP, and the effective dose of almost residents by inhalation of radon and its progeny was higher than the value of Korean $\left(1.27 \mathrm{mSv} \cdot \mathrm{y}^{-1}\right)$ [11] and worldwide average value $\left(1.15 \mathrm{mSv} \cdot \mathrm{y}^{-1}\right)$ [2]. The residents were exposed to more than half of the annual effective dose in winter season (Figure 2). As mentioned previously, because of the high indoor radon concentration in surveyed dwellings near the registered uranium mining lot areas and the influence of stack effect, indoor radon concentration in winter season was higher than any other season (Table 1). In addition, the residential time in winter season was much than any other season (Table 2). Therefore, effective dose in winter season was higher than any other season, and it contributed to increase the high annual effective dose.

\section{CONCLUSION}

This study was conducted for the seasonal survey on indoor radon concentration in some dwellings near the registered uranium mining lot areas which is considered as one of the potential radon-prone areas. Based on the seasonal residential time of residents, the exposure dose to the residents in these 
Table 3. The seasonal effective dose and the annual effective dose in each dwelling.

\begin{tabular}{|c|c|c|c|c|c|c|}
\hline \multirow[t]{2}{*}{ Township } & \multirow{2}{*}{$\begin{array}{l}\text { Dwellings } \\
\text { code }\end{array}$} & \multicolumn{4}{|c|}{ Seasonal effective dose $\left(\mathbf{m S v} \cdot \mathbf{y}^{-(1 / 4)}\right)$} & \multirow{2}{*}{$\begin{array}{c}\text { Annual } \\
\text { effective } \\
\text { dose } \\
\left(\mathrm{mSv} \cdot \mathbf{y}^{-1}\right)\end{array}$} \\
\hline & & $\mathbf{1}^{\text {st }}$ (Spring) & $2^{\text {nd }}($ Summer $)$ & $3^{\text {rd }}($ Fall $)$ & $4^{\text {th }}$ (Winter) & \\
\hline \multirow{2}{*}{ Sangso(SS) } & SS-1 & 1.77 & 0.93 & 2.16 & 7.76 & 12.6 \\
\hline & SS-2 & 0.17 & 0.13 & 0.23 & 0.91 & 1.43 \\
\hline \multirow{11}{*}{$\begin{array}{l}\text { Cheongcheon } \\
\text { (CC) }\end{array}$} & CC-1 & 0.75 & 0.44 & 1.83 & 4.34 & 7.36 \\
\hline & CC-2 & 2.42 & 0.22 & 2.23 & 10.9 & 15.8 \\
\hline & CC-3 & 0.15 & 0.13 & 0.19 & 0.47 & 0.94 \\
\hline & CC-4 & 0.19 & 0.18 & 0.35 & 1.14 & 1.87 \\
\hline & CC-5 & 3.61 & 0.38 & 3.67 & 12.8 & 20.5 \\
\hline & CC-6 & 1.94 & 1.22 & 4.09 & 9.57 & 16.8 \\
\hline & CC-7 & 2.53 & 0.62 & 2.93 & 10.4 & 16.5 \\
\hline & CC-8 & 1.91 & 0.33 & 1.51 & 16.7 & 20.4 \\
\hline & CC-9 & 0.46 & 0.22 & 0.69 & 3.45 & 4.82 \\
\hline & CC-10 & 1.34 & 0.13 & 2.13 & 7.10 & 10.7 \\
\hline & CC-11 & 0.25 & 0.24 & 0.18 & 0.59 & 1.26 \\
\hline \multirow{7}{*}{ Chubu(CB) } & CB-1 & 0.78 & 0.20 & 1.16 & 4.70 & 6.84 \\
\hline & CB-2 & 1.95 & 0.10 & 3.53 & 10.7 & 16.3 \\
\hline & CB-3 & 0.17 & 0.17 & 0.30 & 0.52 & 1.17 \\
\hline & CB-4 & 1.41 & 0.14 & 1.16 & 4.93 & 7.64 \\
\hline & CB-5 & 2.03 & 0.21 & 1.20 & 5.61 & 9.04 \\
\hline & CB-6 & 0.33 & 0.19 & 0.38 & 0.52 & 1.42 \\
\hline & CB-7 & 2.67 & 0.42 & 1.53 & 6.55 & 11.2 \\
\hline
\end{tabular}

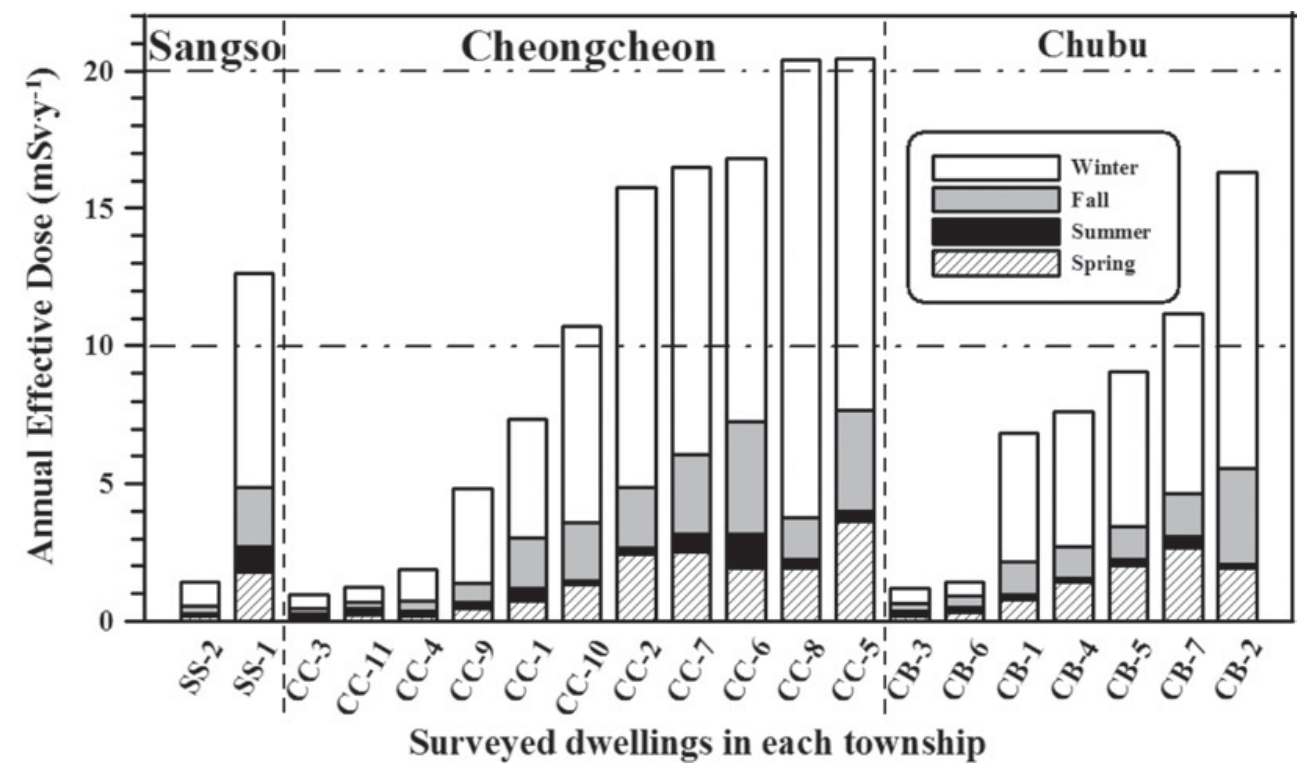

Figure 2. Graph of the seasonal effective dose and the annual effective dose in each dwelling. 
dwellings was assessed in detail. Indoor radon concentrations in some dwellings near the registered uranium mining lot areas were relatively high except several dwellings. Some dwellings were shown significantly high radon concentrations (up to $600 \mathrm{~Bq} \cdot \mathrm{m}^{-3}$ ) and there are required for requiring the mitigation urgently. Some residents in these areas were exposed to high radiation dose. Especially, the effective dose in winter season was dominant than any other seasons, because indoor radon concentration is higher and residential time is longer than any other seasons. So, it needs to focus on the management of exposure in winter season. The result of this survey indicated that applying a seasonal residential time is more efficient way to enhance the accuracy for evaluation of the annual effective dose due to radon.

\section{Acknowledgments}

This study was supported by the Nuclear Technology R\&D program of the Ministry of Education, Science and Technology (MEST) in Korea.

\section{References}

[1] Health Protection Agency, Radon and Public Health. Report of the independent Advisory Group on Ionising Radiation, (Health Protection Agency, RCE-11, 2009)

[2] United Nations Scientific Committee on the Effects of Atomic Radiation, Exposures from natural radiation sources. UNSCEAR 2000 Report to the General Assembly, Annex B (UNSCEAR, 2000).

[3] ICRP International Commission on Radiological Protection. Protection against Radon-222 at Home and Work. (ICRP Publication 65. Ann. ICRP 23/2, 1993).

[4] Kim Y. J., Chang B. U., Park H. M., Kim C. K., and Tokonami S., National Radon Survey in Korea, Radiation Protection Dosimetry (2011), Accepted in press (doi:10.1093/rpd/ncr094)

[5] Kim C. K., Lee S. C., Lee D. M., Chang B. U., Rho B. H., and Kang H. D., National survey of radon levels in Korea, Health Phys 84 (2003) 354-360.

[6] Kim Y. J., Lee H. Y., Kim C. S., Chang B. U., Rho B. H., Kim C. K., and Tokonami, S. Indoor radon, thoron, and thoron daughter concentrations in Korea. Inter. Congress Series 1276 (2005) $46-49$

[7] The Geological Society of Korea, Geology of Korea, (Sigmapress, Korea, 1999) p. 546. in Korean

[8] Tokonami, S., Takahashi, H., Kobayashi, Y., and Zhuo, W., Up-to-date radon-thoron discriminative detector for a large scale survey, Rev. Sci. Instrum 76, 113505 (2005).

[9] ICRP International Commission on Radiological Protection. ICRP Statement on radon, ICRP Committee release, Ref 00/902/09 (2009).

[10] Hubbard, L.M.; Hagberg, N.; Enflo, A. Temperature effect on radon dynamics in two Swedish dwellings, Radiation Protection Dosimetry 45 (1992) 381-386

[11] Korea Institute of Nuclear Safety, Radiation environment in Korea (Korea Institute Nuclear Safety, Korea, 2009) in Korean 